\title{
Toll-Iike Receptor-3 Activation Enhances Malignant Traits in Human Breast Cancer Cells Through Hypoxia-inducible Factor-1 $\alpha$
}

\author{
FRANCESCA SCATOZZA ${ }^{1 *}$, ANTONELLA D'AMORE $^{1 *}$, ROSARIA ANNA FONTANELLA $^{1}$, PAOLA DE CESARIS $^{2}$, \\ FRANCESCO MARAMPON ${ }^{3}$, FABRIZIO PADULA $^{1}$, ELIO ZIPARO ${ }^{1}$, ANNA RICCIOLI $^{1}$ and ANTONIO FILIPPINI ${ }^{1}$ \\ ${ }^{1}$ Department of Anatomy, Histology, Forensic Medicine and Orthopedics, \\ Unit of Histology and Medical Embryology, Sapienza University of Rome, Rome, Italy; \\ ${ }^{2}$ Department of Biotechnological and Applied Clinical Sciences, University of L'Aquila, L'Aquila, Italy; \\ ${ }^{3}$ Department of Radiotherapy, Sapienza University of Rome, Rome, Italy
}

\begin{abstract}
Background/Aim: Hypoxia-inducible factor 1 (HIF 1) inhibitors have been proposed as therapeutic agents for several tumor types. HIF $1 \alpha$ is induced by hypoxia and by pathogens in normoxia through toll-like receptors (TLRs). The TLR3 activator polyinosinic:polycytidylic acid [poly(I:C)] induces apoptosis in various types of cancer but not in the most aggressive breast cancer cell lines. We hypothesized that the failure of TLR3 stimulation to induce apoptosis in these cells might be due to an elevated HIF $1 \alpha$ level and this link might be exploited. Materials and Methods: Poly(I:C)-induced signaling pathway and expression of HIF $1 \alpha$ and HIF $1 \alpha$ targets were studied in MDA MB-231 and MCF-7 breast cancer cell lines by western blot. Flow cytometry was used for apoptotic responses and vasculogenic mimicry as bioassay. Results: Poly(I:C) increased expression of HIF $1 \alpha$ and its targets BCL2 apoptosis regulator and cMYC. Moreover, using pharmacological or genetic HIF 1 inhibition, reduction of poly $(I: C)$-induced expression of HIF $1 \alpha$ was paralleled by lowering of c-MYC and increased sensitivity to poly(I:C)-induced apoptosis, demonstrating the crucial role of this factor. We provide the first evidence in breast cancer cells that TLR3 stimulation induces HIF $1 \alpha$ dependent vasculogenic mimicry. By using specific inhibitors, we identified a signaling cascade upstream of HIFl $\alpha$
\end{abstract}

This article is freely accessible online.

*These Authors contributed equally to this study.

Correspondence to: Anna Riccioli, Department of Anatomy, Histology, Forensic Medicine and Orthopaedics, Unit of Histology and Medical Embryology, Sapienza University of Rome, 16 Via A. Scarpa, 00161 Rome, Italy. E-mail: anna.riccioli@uniroma1.it

Key Words: HIF1 $\alpha$, vasculogenic mimicry, HIF1 inhibitors, apoptosis, acriflavine. induction. Conclusion: Combined treatment with poly(I:C) and HIF 1 inhibitors deserves consideration as an effective strategy in breast cancer therapy.

Breast cancer is the most common invasive cancer in women and is associated with a high mortality index in the female population worldwide; indeed, this cancer represents the second cause of cancer death in women (1). Most patients with advanced breast cancer die primarily as a result of distant metastases. The rapid growth of tumor cells leads to hypoxia in the tumor microenvironment [about $1 \%$ oxygen $\left(\mathrm{O}_{2}\right)$ ], which can further promote breast cancer development and metastasis $(2,3)$. Hypoxia results from the altered balance between the supply and consumption of $\mathrm{O}_{2}$ and is defined as an oxygen level lower than the approximate $7 \%$ (normoxia) observed in normal and wellvascularized tissues (4). Cells respond to the reduction of $\mathrm{O}_{2}$ through the activation of hypoxia-inducible factor-1 (HIF1), a key mediator of the cellular response to hypoxia. HIF1 is a heterodimeric basic-helix-loop-helixtranscription factor consisting of two proteins: an oxygenregulated subunit HIF1 $\alpha$ (or its parologs HIF2 $\alpha$ and HIF3 $\alpha$ ) and a constitutively expressed subunit HIF1 $\beta$ (5). HIF $1 \alpha$ protein has a short half-life $\left(\mathrm{t}_{1 / 2}=5 \mathrm{~min}\right)$ and its levels are regulated by the oxygen-dependent enzyme proline hydroxylase. In normoxia, HIF1 $\alpha$ level is low because it is hydroxylated by prolyl hydroxylase domain proteins, which are responsible for the binding of the tumor suppressor von Hippel-Lindau complex, resulting in proteasomal degradation of HIF1 $\alpha$ (5). During hypoxia, this enzyme is inhibited and the stabilized HIF1 $\alpha$ is translocated to the nucleus, where, after dimerization with HIF $1 \beta$ and recruitment of several coactivators, it forms the HIF1 complex that binds specific regions of promoters, named hypoxia-responsive elements (6), activating the transcription of HIF1 target genes. These genes are 
involved in various crucial mechanisms of breast cancer biology, such as stem cell maintenance, metabolic reprogramming, angiogenesis, epithelial mesenchymal transition, metastasis and resistance to radiation and chemotherapy (2, 7). Interestingly, using HIF1 $\alpha$ as a marker for hypoxia, approximately $25-40 \%$ of all invasive breast cancers have been shown to exhibit hypoxic areas (4). Although HIF1 $\alpha$ protein is induced by hypoxic conditions, there are other stimuli capable of strongly increasing the formation of the HIF1 complex in normoxia and of modulating the transcription of hypoxic genes (8). These non-hypoxic stimuli include cytokines, such as tumor necrosis factor- $\alpha$, interleukin- $1 \beta$ and interferon- $\alpha$, reactive nitrogen- or oxygen-derived radicals, growth factors, such as insulin-like growth factor-1 (9-12). Moreover, a variety of bacterial and viral components have been described as activating HIF1 $\alpha$ in normoxia by triggering their specific toll-like receptors (TLRs) $(13,14)$. TLRs are a group of trans-membrane proteins that bind pathogen-associated molecular patterns conserved in bacteria, viruses and parasites (15). Most studies have shown that TLRs expressed on immune cells enhance the effects of tumor vaccines or of chemotherapy by improving antitumor immune responses, reviewed in (16), while expression of TLRs on tumor cells is reported to induce tumor progression by enhancing anti-apoptotic and pro-survival signals, the production of tumor-promoting cytokines, angiogenesis and invasiveness (17).

Intriguingly, stimulation of TLR3 expressed in several breast tumor cell lines has been shown to trigger a proapoptotic signal cascade leading to the inhibition of tumor growth $(18,19)$. Moreover, the highly expressed TLR3, TLR4 and TLR9 in human breast cancer may represent therapeutic targets because their levels of expression have clinical interest as indicators of tumor aggressiveness (20). Conversely, it has been recently shown that under stimulation of TLR3 two double-negative breast cancer cells lines acquire a cancer stem cell phenotype in vitro and in vivo (21), and inhibition of TLR3 signaling in combination with tamoxifen may increase the effectiveness of current treatments of breast cancer (22). Accordingly, our group previously demonstrated that stimulation of TLR3 expression induced apoptosis in the androgen-dependent LNCaP prostate cancer cell line in vitro (23) and in vivo (24), whereas it induced angiogenesis and apoptosis resistance through HIF1 complex activation in the more aggressive androgen-independent PC3 and DU-145 prostate cancer cells (25).

In this study, we aimed to examine whether TLR3 stimulation by its specific agonist polyinosinic:polycytidylic acid [poly(I:C)] induced HIF1 $\alpha$ accumulation in breast cancer cell lines insensitive to TLR3-induced apoptosis and differing in hormone-resistance, and whether HIF1 activity correlated with protumor responses. The signal transduction triggered by TLR3 agonist involved in HIF1 $\alpha$-induced upregulation was also investigated.

Besides induction of protumor and anti-apoptotic genes, hypoxia and subsequent HIF1 overexpression in tumor cells can promote a phenomenon involved in tumor progression called vasculogenic mimicry (VM) (26). VM, a strategy developed by solid tumors to grow and spread, is the formation of vessel-like channels that are not formed from pre-existing vessels, do not involve endothelial cells and hence are not true blood vessels but mimic their role, allowing for blood flow and oxygenation. Hypoxic conditions not only induce VM formation but also favor tumor metastasis and increase the risk of resistance to chemotherapy in breast cancer (27). After the first observations in melanoma $(28,29)$, the presence of VM has been described in other types of human cancer such as renal cell carcinoma (30), colorectal cancer (31), prostate cancer (32), glioblastoma (33), ovarian carcinoma (34), gastric adenocarcinoma (35), hepatocellular carcinoma (36), laryngeal squamous cell carcinoma (37) and breast cancer (38). Although microenvironmental factors and various proteins are recognized to modulate $\mathrm{VM}$, the mechanism that regulates it remains unclear. In a model of triple-negative breast cancer cells (TNBC) clinically characterized by fast growth, high invasive ability and no available targeted treatment, it was suggested that HIF1 might play a key role in the biological mechanisms of this malignancy (39). Considering the multiple roles of HIF1 complex in tumor progression and metastasis, in the present study we investigated the possible causal link between HIF1 $\alpha$ and VM in TNBC. Our data from both genetic and pharmacological approaches show that HIF1 $\alpha$ activation is necessary for the formation of VM in this highly metastatic malignancy. The present experimental evidence brings support to the proposed use of HIF1 $\alpha$ inhibitors in combined therapy for breast cancer with other agents that further promote tumor hypoxia, such as angiogenesis inhibitors, or in combination with conventional chemotherapy or ionizing radiation $(40,41)$.

\section{Materials and Methods}

Cell cultures and reagents. Breast cancer cell lines MDA-MB-231 and MCF-7 were purchased from the American Type Culture Collection (Manassas, VA, USA) and grown in Dulbecco's modified Eagle's medium (Sigma-Aldrich, St Louis, MO USA), supplemented with $10 \%$ fetal bovine serum (FBS) (Sigma-Aldrich), $2 \mathrm{mM}$ glutamine (Sigma-Aldrich) and $100 \mathrm{mM}$ penicillin/streptomycin (Sigma-Aldrich). For all the experiments cells were serum-starved for 18 hours and then treated with high molecular weight polyI:C at 25 $\mu \mathrm{g} / \mathrm{ml}$ (InvivoGen, San Diego, CA USA) in FBS-free medium. HIF inhibitor acriflavine and nuclear factor $\mathrm{kB}(\mathrm{NF}-\mathrm{kB})$ inhibitor BAY 117082 were from Sigma-Aldrich, and extracellular-regulated kinase (ERK) inhibitor UO126 was from Calbiochem (San Diego, CA, USA). Matrigel was from BD Biosciences (San Diego, CA, USA). 
Transfection assay. One day after plating $\left(8 \times 10^{4} \mathrm{cells} / \mathrm{ml}\right)$, cells were transfected with Lipofectamine 2000 (Invitrogen, Carlsbad, CA, USA) plus $10 \mathrm{nM}$ siRNA targeting HIF1 $\alpha$ (Qiagen, Venlo, the Netherlands) or the relative control siRNA (scramble), overnight. The next day, the cells were treated with poly(I:C) at $25 \mu \mathrm{g} / \mathrm{ml}$ in FBSfree medium for different times depending on the assay performed.

Western blot analysis and preparation of nuclear extracts. Cells were washed with cold PBS and lysates were prepared in cell lysis buffer (Cell Signaling, Danvers, MA, USA), 1\% sodium dodecylsulphatepolyacrylamide (Sigma-Aldrich) and $1 \mathrm{mM}$ Phenylmethanesulfonyl fluoride solution (Sigma-Aldrich). Preparation of nuclear extracts to detect nuclear HIF1 $\alpha$ was performed as described elsewhere (25). Protein concentration was determined by bicinchoninic acid Protein Assay Kit (Pierce, Rockford, IL, USA) according to the manufacturer's instructions and then equal amounts of proteins $(25 \mu \mathrm{g})$ were subjected to dodecylsulphate-polyacrylamide gel electrophoresis and transferred onto nitrocellulose membrane (GE Healthcare Life Science, Vienna, Austria). Membranes were saturated with $5 \%$ non-fat dry milk, incubated with the primary antibody at $4^{\circ} \mathrm{C}$ overnight and subsequently with horseradish peroxidase-conjugated secondary antibody for $1 \mathrm{~h}$ at room temperature. Membranes were then washed with T-TBS and developed using the chemiluminescence system (ECL Advance; Amersham Biosciences, San Diego, CA, USA). Anti-HIF1 $\alpha$ was from BD Bioscences (San Diego, CA, USA); anti-c-MYC and anti-BCL2 apoptosis regulator (BCL2) were from Santa Cruz Biotechnology (Santa Cruz, CA, USA); antibodies against phospho-NF-kB p65, TLR3, survivin and phospho-ERK were from Cell Signaling; anti- $\beta$-actin and anti- $\alpha$-tubulin were from Sigma; anti-proliferating cell nuclear antigen (PCNA) was from Abcam (San Francisco, CA, USA). Secondary antibodies were horseradish peroxidase-conjugated goat anti-mouse or anti-rabbit (Bio-Rad, Hercules, CA, USA). The intensity of western blot bands was quantified by Chemidoc Gel Imaging System Image Lab 5.2.1. software (Bio-Rad) from three independent experiments.

VM assay. Firstly, 24-well plates were coated with cold matrigel (150 $\mu \mathrm{l} /$ well) and incubated at $37^{\circ} \mathrm{C}$ for $1 \mathrm{~h}$ until the gel solidified. Prior to seeding, MDA-MB-231 cells had been treated in suspension with 25 $\mu \mathrm{g} / \mathrm{ml}$ poly(I:C) or $100 \mu \mathrm{M} \mathrm{CoCl}_{2}$ (Sigma-Aldrich) for $3 \mathrm{~h}$. In HIF1 $\alpha$ inhibition experiments, the cells were pretreated with $5 \mu \mathrm{M}$ acriflavine for $8 \mathrm{~h}$, prior to the addition of $25 \mu \mathrm{g} / \mathrm{ml}$ poly(I:C). Moreover, we pretreated cells with $5 \mu \mathrm{M}$ acriflavine for $8 \mathrm{~h}$ before the addition of 100 $\mu \mathrm{M} \mathrm{CoCl}{ }_{2}$, then we removed the medium and added $25 \mu \mathrm{g} / \mathrm{ml}$ poly(I:C) to the cells. To test the inhibition of VM after genetic downregulation of HIF1 $\alpha$, we transfected MDA-MB-231 cells with Lipofectamine 2000 (Invitrogen) plus $10 \mathrm{nM}$ siRNA targeting HIF1 $\alpha$ (Qiagen, Venlo, the Netherlands) or control siRNA (scramble) overnight. The formation of vessel-like channels was analyzed $16 \mathrm{~h}$ after plating. Images were then captured under an Eclipse TS100 ELWD $0.3 /=$ D75 T1-SNCP inverted microscope (Nikon, Tokyo, Japan). The vessel-like channels were counted as the total number of closed polygons in random microscope fields. Eight fields/well were assessed and three experiments in triplicate were performed.

Apoptosis assays. To detect apoptotic cells using propidium iodide (PI) staining, cells were untreated or treated with $5 \mu \mathrm{M}$ acriflavine for $8 \mathrm{~h}$ and then with/without $25 \mu \mathrm{g} / \mathrm{ml}$ poly(I:C) for 48 and $72 \mathrm{~h}$ and were then harvested by trypsin, washed with cold phosphate-buffered saline (PBS)-5\% FBS and fixed in 70\% ethanol for $24 \mathrm{~h}$. After washing with PBS, cells were incubated with $1 \mu \mathrm{g} / \mathrm{ml}$ PI (Sigma) for
$3 \mathrm{~h}$ at room temperature, and then examined in a CyAn ADP flow cytometer (Beckman Coulter, Brea, CA, USA). When cell DNA content was lower than $2 \mathrm{~N}$ (sub- $\mathrm{G}_{1}$ cell population), cells were considered apoptotic. For annexin $\mathrm{V}$ staining, the cells were detached with trypsin, washed with PBS and then stained with annexin Vfluorescein isothiocyanate in a buffer containing PI. Annexin Vpositive PI-negative cells were considered early apoptotic, while annexin V-positive PI-positive cells were considered late apoptotic.

Statistical analysis. All data are presented as the mean \pm SEM resulting from at least three independent experiments. Student's $t$ test was used for statistical comparison between means where applicable. $p$-Values of 0.05 or less were considered significant.

\section{Results}

TLR3 stimulation induces HIFl $\alpha$ and regulates HIF $1 \alpha$ target proteins up in human breast cancer cell lines insensitive to TLR3-induced apoptosis. We examined if TLR3 stimulation by its specific agonist poly(I:C) modulated the expression of HIF1 $\alpha$ protein in two breast cancer cell lines: MDA-MB231, a TNBC cell line (lacking estrogen, progesterone and epidermal growth factor receptors) and MCF-7, a triplepositive breast cancer cell line (estrogen- and progesteronedependent), which are known to be insensitive to poly(I:C)induced apoptosis (19). The cells were treated with $25 \mu \mathrm{g} / \mathrm{ml}$ poly(I:C) and the level of HIF1 $\alpha$ was evaluated in total cell lysates by western blot. In MDA-MB-231 and MCF-7 cells increased levels of HIF1 $\alpha$ were observed after poly(I:C) treatment up to $24 \mathrm{~h}$ (Figure 1A and B). Since activated HIF1 $\alpha$ rapidly moves into the nucleus, we evaluated HIF1 $\alpha$ expression in nuclear extracts in poly(I:C)-treated MDA-MB231 cells. Our data demonstrate HIF1 $\alpha$ nuclear translocation starting from $16 \mathrm{~h}$ poly(I:C) treatment (Figure 1C).

Interestingly, we previously reported that poly(I:C) induced an increase in expression of TLR3 in prostate cancer cells (42), which prompted us to examine this effect in breast cancer. Figure 1D shows that in MDA-MB-231 cells, TLR3 was significantly up-regulated upon poly(I:C) stimulation after 16 and $24 \mathrm{~h}$.

Moreover, as the oncogene c-MYC and the anti-apoptotic genes BCL2 and survivin are known to be putative targets of HIF1 $\alpha$ (43-45), MDA-MB-231 and MCF-7 cells were treated with poly(I:C) for different times and the expression of these proteins was evaluated by western blot. A significant increase in c-MYC was observed at 16 and $24 \mathrm{~h}$ both in total cell lysates (Figure 2A) and in the nuclear extracts (Figure 2B); in MCF-7 total lysates, the c-MYC expression level peaked at $4 \mathrm{~h}$ (Figure 2C).

In addition, BCL2 protein expression was enhanced after 16 $\mathrm{h}$ and $24 \mathrm{~h}$ poly(I:C) treatment (Figure 3A) in MDA-MB-231 cells but not in MCF-7 cells (Figure 3C). Conversely, expression of survivin, a unique member of the inhibitor of apoptosis protein family, was significantly increased in MCF7 cells treated with poly(I:C) (Figure 3D) but not in MDA-MB- 
MDAMB-231 cell lysate

A
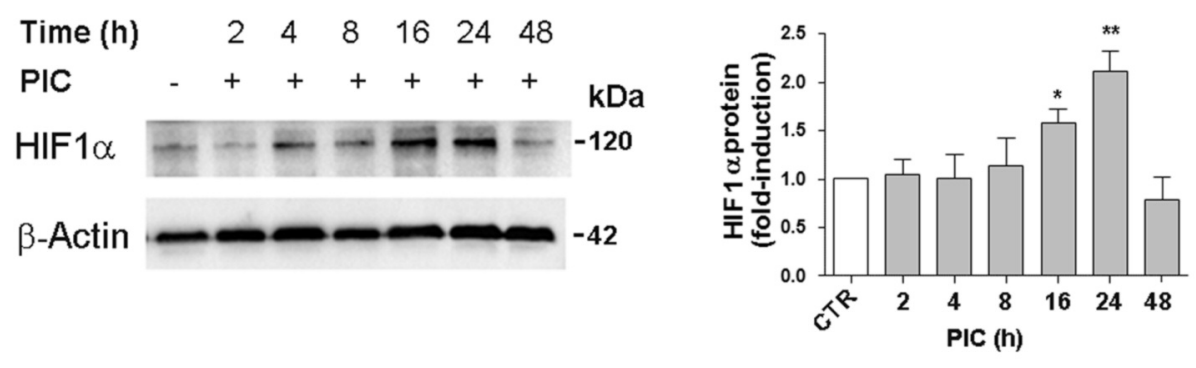

B

MCF-7 cell lysate
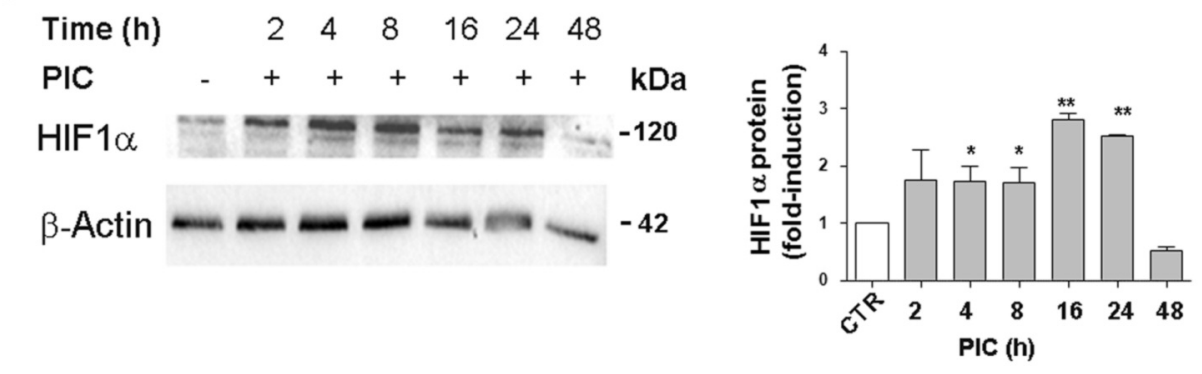

C

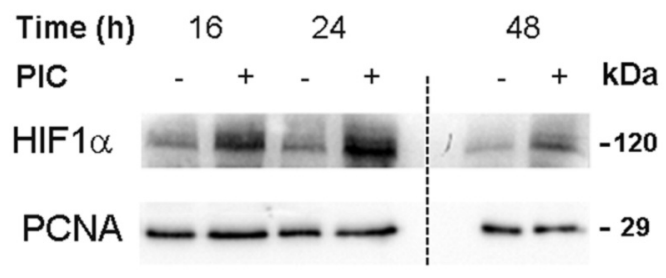

\section{MDAMB-231 nuclear extract}

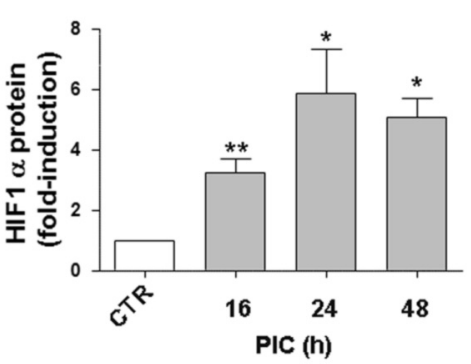

MDAMB-231 cell lysate

D
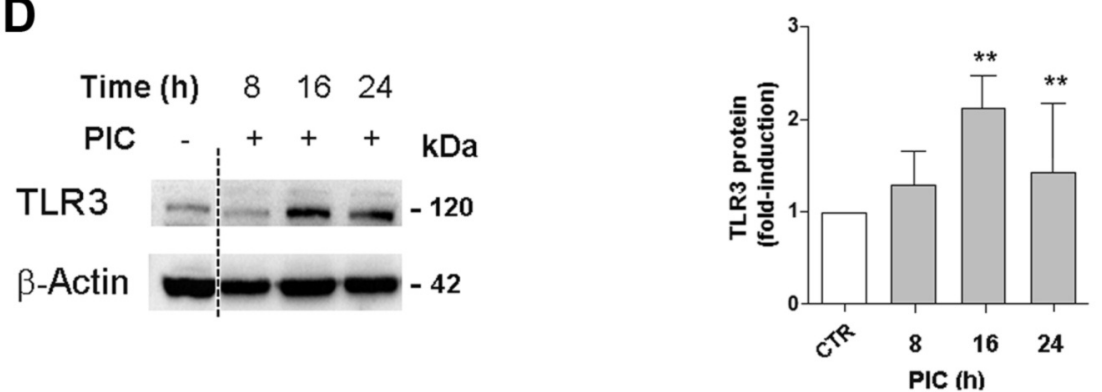

Figure 1. Effect of polyinosinic:polycytidylic acid (PIC) on hypoxia-inducible factor $1 \alpha$ (HIF1 $\alpha$ ) accumulation in MDA-MB-231 and MCF-7 cells. Cells were stimulated with PIC for the indicated times and whole-cell extracts were analyzed by western blot (left panel) and quantified (right panel) for HIF1a $(A, B, C)$. Western blots and quantification of toll-like receptor-3 (TLR3) in nuclear extracts from MDA-MB-231 cells treated with PIC are shown in D. The histograms represent the densitometric analysis of three separate experiments with the value of untreated cells set as 1. $\beta$-Actin and proliferating cell nuclear antigen (PCNA) were used to control for equal loading of proteins or whole and nuclear extracts, respectively. Significantly different from the control (CTR) at * $p<0.05$, and $* * p<0.01$. 


\section{A \\ MDAMB-231 cell lysate}
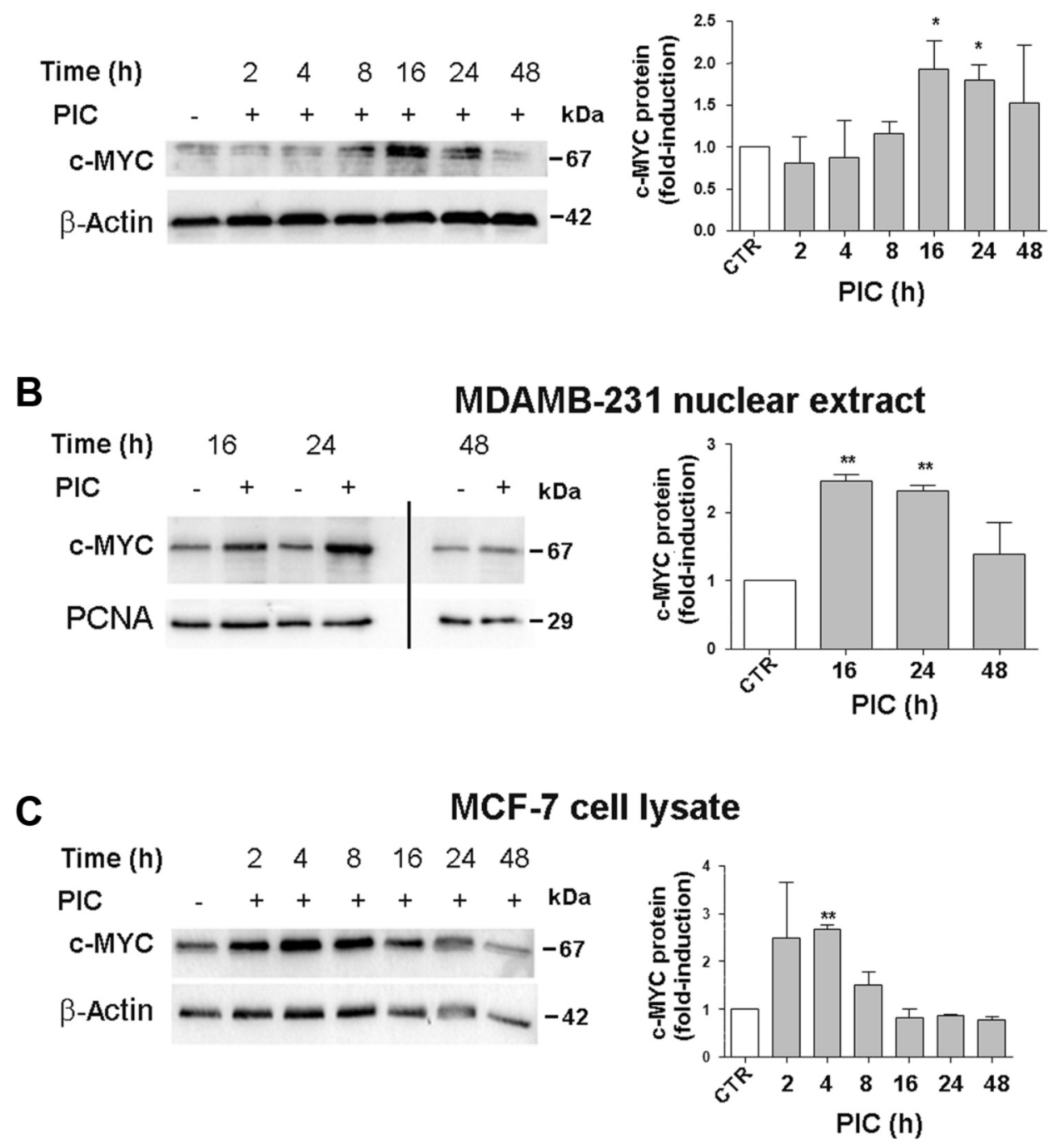

Figure 2. Effect of polyinosinic:polycytidylic acid (PIC) on c-MYC expression in MDA-MB-231 and MCF-7 cells. Cells were stimulated with PIC for the indicated times and whole-cell extracts of MDA-MB-231 (A) and MCF-7 cells (C) were analyzed by western blot for c-MYC. Western blots and quantification of $c-M Y C$ in nuclear extracts from MDA-MB-231 cells treated with PIC are shown in B. The histograms represent the densitometric analysis of three separate experiments with the value of untreated cells set as 1. $\beta$-Actin and proliferating cell nuclear antigen (PCNA) were used to control for equal loading of proteins of whole-cell and nuclear extracts, respectively. Significantly different from the control (CTR) at $* p<0.05$, and **p<0.01.

231 cells (Figure 3B). These results suggest that up-regulation of HIF1 $\alpha$ protein induces overexpression of anti-apoptotic and pro-tumor proteins after poly(I:C) stimulation in human breast cancer cell lines insensitive to poly(I:C)-induced apoptosis.

HIF $1 \alpha$ inhibition promotes sensitivity to poly(I:C)-induced apoptosis and reduces up-regulation of $c-M Y C$ and TLR3 proteins in MDA-MB-231 cell line. Experimental evidence on different cell types reported an anti-apoptotic role for HIF1 $\alpha(25,46,47)$, therefore, given the low sensitivity of MDA-MB-231 cells to poly(I:C)-induced apoptosis (48), through pharmacological HIF1 $\alpha$ inhibition, we investigated whether HIF1 $\alpha$ plays a role in resistance to this apoptotic stimulus in these cells. MDA-MB-231 cells were pre-treated with $5 \mu \mathrm{M}$ acriflavine, an FDA-approved small molecule HIF1 inhibitor (49), for $8 \mathrm{~h}$ and then with poly(I:C) for 48 and $72 \mathrm{~h}$ and apoptosis was evaluated using PI staining. As shown in Figure 4A, poly(I:C)-induced apoptosis was increased in acriflavine/poly(I:C)-treated cells compared with those treated with poly(I:C) alone only slightly after $48 \mathrm{~h}$ but more markedly after $72 \mathrm{~h}$. Figure 4B shows the inhibitory effect of acriflavine on HIF1 $\alpha$ protein expression. 
A

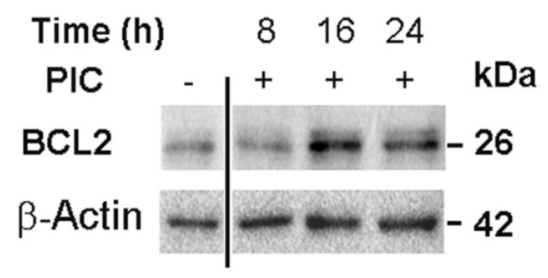

MDAMB-231 cells

B
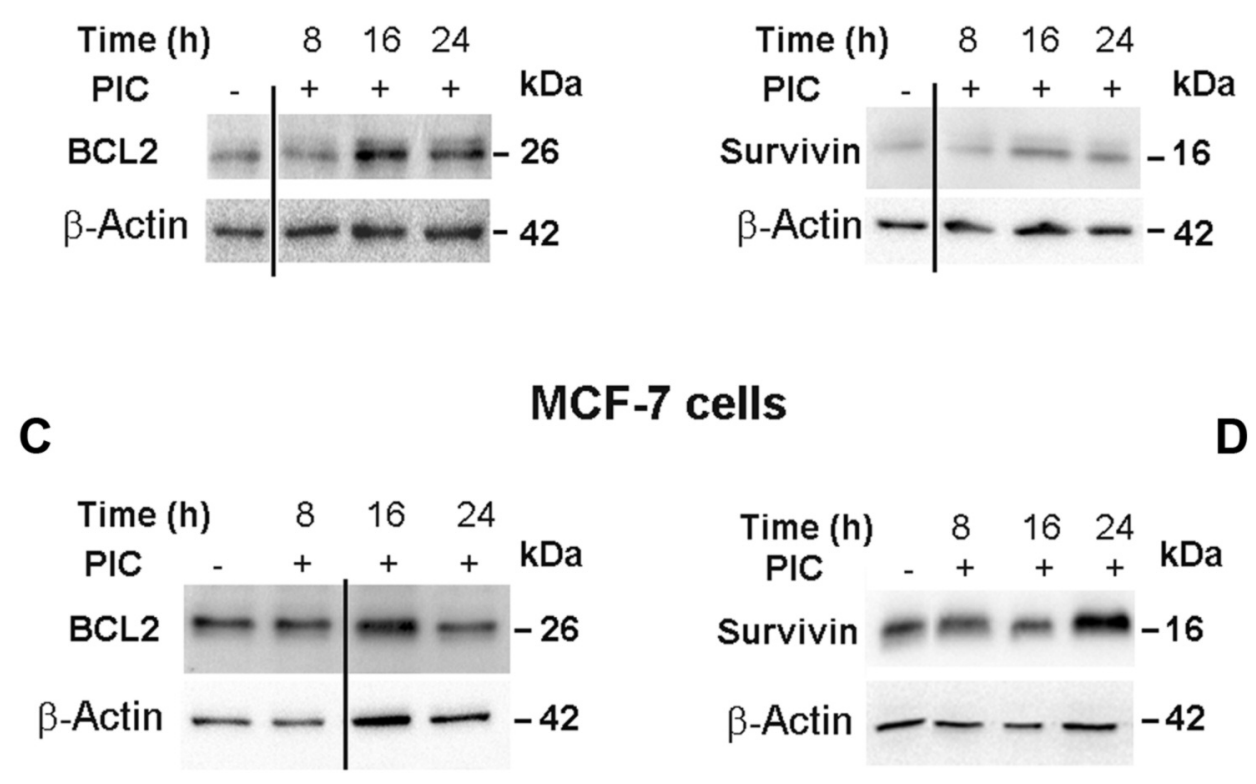

MCF-7 cells

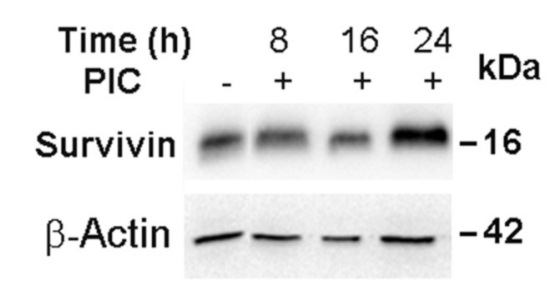

Figure 3. Effect of polyinosinic:polycytidylic acid (PIC) on BCL2 apoptosis regulator (BCL2) and survivin expression in MDA-MB-231 (A, B) and MCF-7 cells $(C, D)$. Both cell lines were stimulated with PIC for the indicated times and whole-cell extracts were analyzed by western blot for BCL2 (left panel) and survivin (right panel). $\beta$-Actin was used to control for equal loading of proteins. Each blot is representative of three.
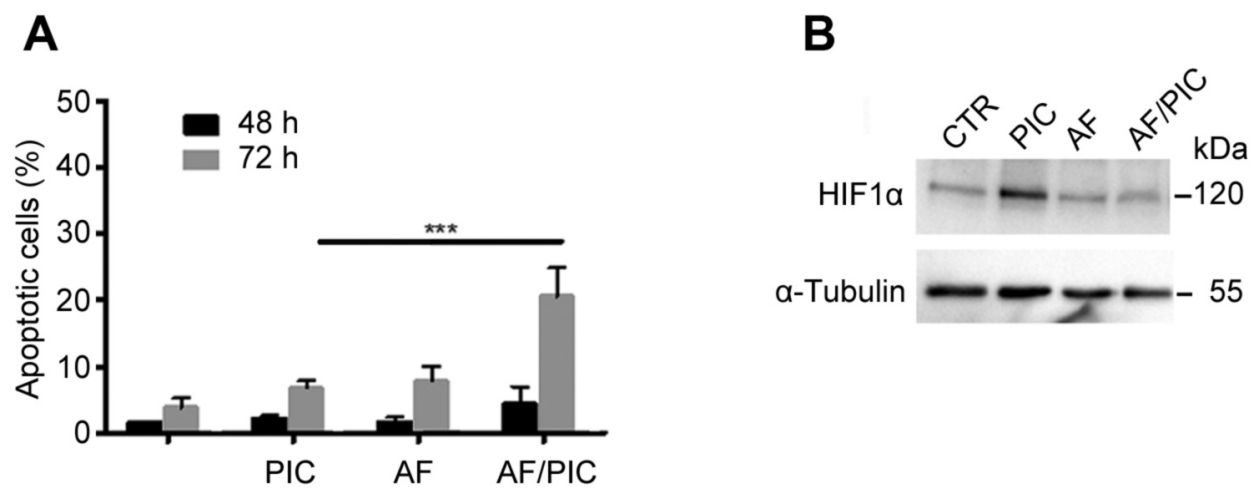

Figure 4. Effects of hypoxia-inducible factor 1 (HIF1) inhibitor acriflavine (AF) on polyinosinic:polycytidylic acid (PIC)-mediated apoptosis of MDA-MB-231. A: Apoptosis as shown by propidium iodide staining of MDA-MB-231 cells treated with $5 \mu M$ AF for the indicated times. By flow cytometry, when the cell DNA content was a peak lower than $2 N\left(\right.$ sub-G $G_{l}$ cell population), cells were considered apoptotic. Data represent the mean of three independent experiments. B: Cells were treated for $16 \mathrm{~h}$ with PIC with/without AF and the whole-cell lysates were analyzes by western blot to evaluate c-MYC expression. $\beta$-Actin was used to control for equal loading of proteins of whole-cell extracts. The blot is representative of three. ***Significantly different from the control (CTR) at $p<0.001$.

To investigate whether the up-regulation of HIF1 $\alpha$ is crucial for overexpression of c-MYC and TLR3 proteins after poly(I:C) treatment, MDA-MB-231 cells were transiently transfected with siRNA targeting HIF1 $\alpha$ or with control siRNA and then treated with poly(I:C). After confirming by western blot that poly(I:C)-induced HIF1 $\alpha$ protein expression was significantly reduced in cells with specific HIF1 $\alpha$ siRNA (Figure 5A), the levels of c-MYC and TLR3 proteins were evaluated. Western blot showed that HIF1 $\alpha$ siRNA significantly inhibited the increase in poly(I:C)-induced cMYC and TLR3 expression (Figure 5B), demonstrating that c-MYC and TLR3 are targets of the HIF1 complex. 

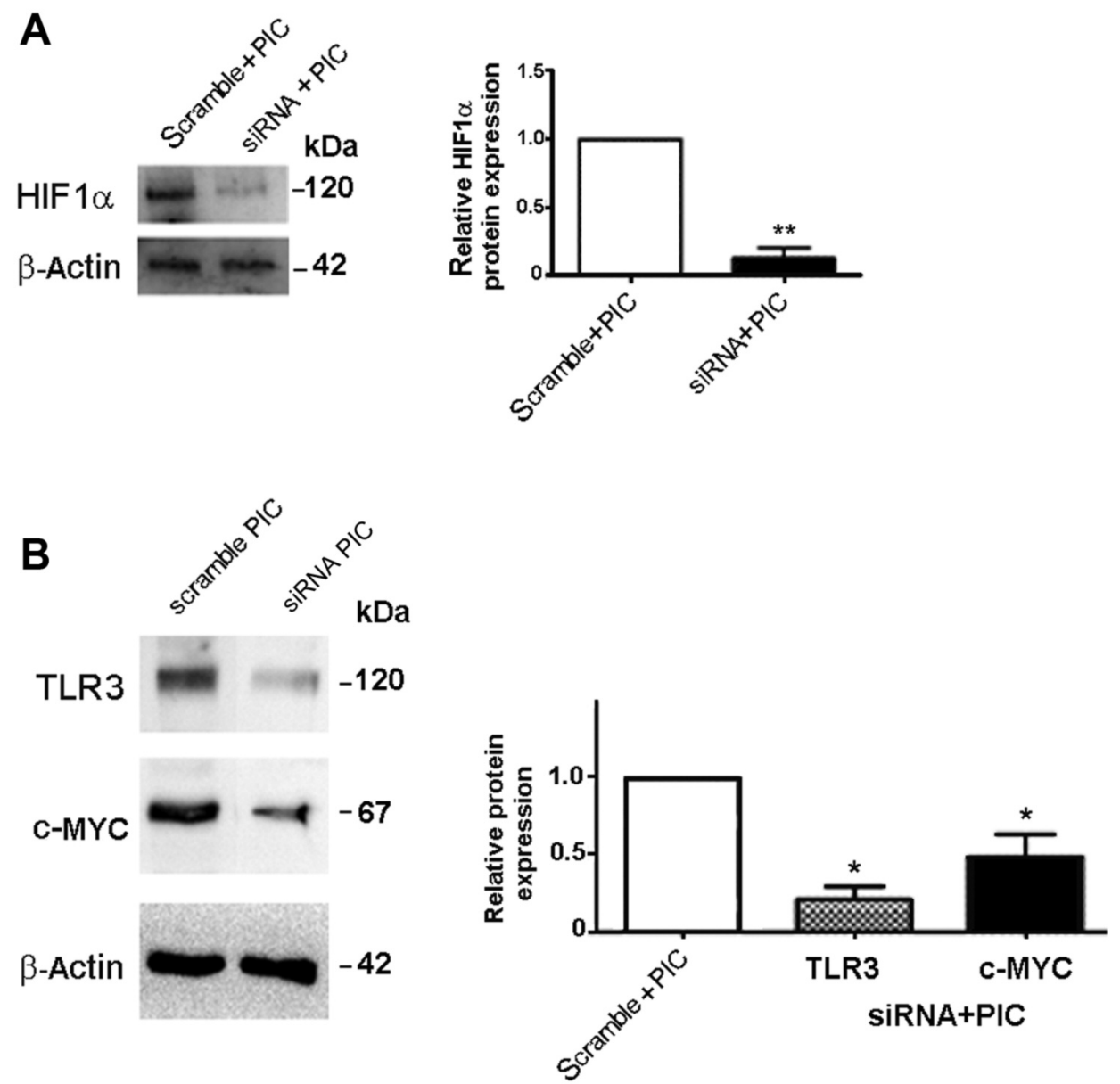

Figure 5. Specific down-regulation of hypoxia-inducible factor $1 \alpha$ (HIFla) inhibits polyinosinic:polycytidylic acid (PIC)-induced c-MYC and tolllike receptor-3 (TLR3) protein expression in MDAMB-231 cells. A: MDA-MB-231 cells were transfected with scramble RNA or siRNA against HIF $1 \alpha$, treated with $25 \mu \mathrm{g} / \mathrm{ml}$ PIC for $16 \mathrm{~h}$, then analyzed for HIF $1 \alpha$ protein by western blot (left panel). B: c-MYC and TLR3 proteins in transfected MDA-MB-231 cells treated with $25 \mu \mathrm{g} / \mathrm{ml}$ PIC for $16 \mathrm{~h}$ were analyzed by western blot (left panel). Densitometric analysis of three separate experiments is shown (right panels). $\beta$-Actin was used to control for equal loading of proteins of whole-cell extracts. Significantly different from scramble + PIC at $* p<0.05$, and $* * p<0.01$.

TLR3 stimulation induces HIF1-dependent VM in MDA-MB231 cells. It has been reported that HIF1 $\alpha$ protein can promote vasculogenic mimicry (VM) in some types of tumors (50). Here we investigated whether poly(I:C)-induced HIF1 $\alpha$ protein promoted the formation of vessel-like channels in MDA-MB-231 cells. As shown in Figure 6A, these cells tend to adopt a chord-like phenotype and formed an arborizing pattern on Matrigel but, interestingly, formed more interlacing VM channels when treated with poly(I:C). To investigate the role of HIF1 $\alpha$ in poly(I:C)-induced VM, we analyzed the effect of acriflavine alone or in combination with poly(I:C) on VM channel formation. HIF1 $\alpha$ inhibitor acriflavine, as single treatment, slightly reduced the basal formation of vessel-like channels in MDA-MB-231 (data not shown), as expected, given the basal expression of HIF $1 \alpha$ in this cell line
(Figure 1). As shown in Figure 6B, HIF1 $\alpha$ inhibitor in combination with poly(I:C) abolished VM channel formation compared to poly(I:C) alone, demonstrating the involvement of HIF $1 \alpha$ in promoting VM following TLR3 stimulation.

To confirm a key role of HIF1 $\alpha$ protein in VM channel formation in breast cancer cells, we investigated the MDAMB-231 VM levels after treatment with $\mathrm{CoCl}_{2}$, a chemical hypoxia-mimetic, that induces stabilization of $\mathrm{HIF} 1 \alpha$ protein. As shown in Figure $6 \mathrm{~B}, \mathrm{CoCl}_{2}$, as well as poly(I:C), promoted the formation of vessel-like channels, whereas in combination with HIF1 $\alpha$ inhibitor acriflavine, this biological feature was markedly reduced. Data obtained after genetic inhibition of HIF1 $\alpha$ confirmed a pivotal role of HIF $1 \alpha$ in VM channel formation in MDA-MB-231 cells after poly(I:C) treatment (Figure 6C). 
A

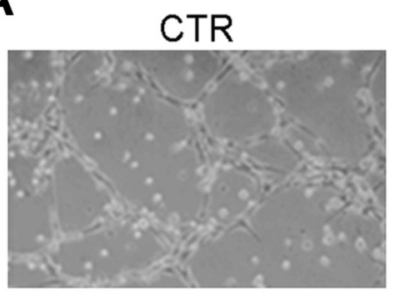

B

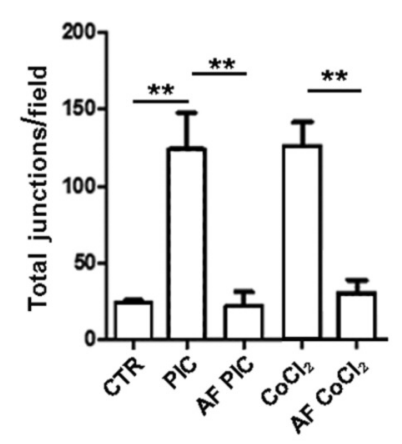

C

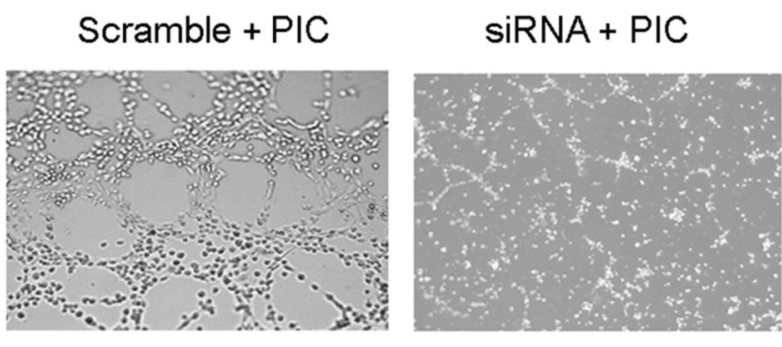

PIC
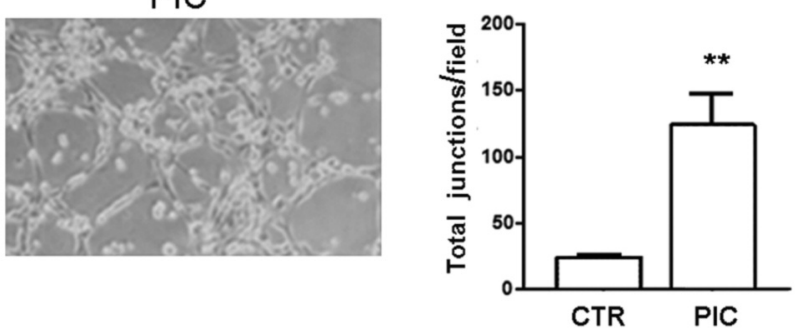

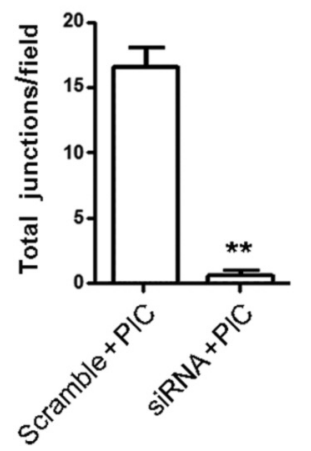

Figure 6. Toll-like receptor-3 (TLR3) stimulation induces hypoxia-inducible factor $1 \alpha$ (HIF1 $\alpha$ )-dependent vasculogenic mimicry (VM) in MDA-MB231 cells. A: After treatment with $25 \mu \mathrm{g} / \mathrm{ml}$ polyinosinic:polycytidylic acid (PIC), MDA-MB-231 cells exhibited typical pipe-like VM networks on Matrigel compared with untreated cells. Representative images of one of three independent experiments are shown (left panel). The vessel-like channels were counted as the total number of closed polygons in random microscopy fields (right panel). In each well, eight fields/well were counted and three experiments in triplicate were performed. B: MDA-MB-231 cells were pretreated with $100 \mu \mathrm{M}$ CoCl2 or $25 \mu \mathrm{g} / \mathrm{mL}$ PIC for $3 \mathrm{~h}$ with or without $5 \mu M$ acriflavine (AF), HIF1 inhibitor. After $16 \mathrm{~h}$, VM formation was analyzed and vessel-like channels were counted. C: Representative images from one of three independent experiments of MDA-MB-231 cells transfected with scramble or HIF1 $\alpha$ siRNA and treated with $25 \mu \mathrm{g} / \mathrm{ml}$ PIC for $16 \mathrm{~h}$ (left panel). The vessel-like channels were counted as total number of closed polygons in random microscope fields (right panel). Significantly different from the control (CTR) or scramble + PIC at ** $p<0.01$.

TLR3 and HIFla up-regulation induced by poly(I:C) stimulation in MDAMB-231 cells is downstream of $N F-k B$ and phospho-ERK activation. Since poly(I:C) is known to activate $\mathrm{NF}-\mathrm{kB}$ and mitogen-activated protein kinases in other cancer cell types (23), in order to evaluate signal transduction pathways upstream of HIF1 $\alpha$ activated by poly(I:C), we analyzed the levels of phospho-p65 NF-kB subunit and phospho-ERK in MDAMB-231 cells after poly(I:C) treatment. Western blot analysis showed an increase of phospho-p65 and phospho-ERK starting from $10 \mathrm{~min}$ up to $20 \mathrm{~min}$ after
poly(I:C) (Figure 7A). To investigate the role of NF-kB and ERK signaling in poly(I:C)-induced expression of HIF1 $\alpha$, cells were pre-treated with BAY 11-7082 and U0126, selective inhibitors of NF-kB and ERK, respectively, before adding poly(I:C). Both inhibitors reduced the level of HIF1 $\alpha$ examined after $24 \mathrm{~h}$ of poly(I:C) treatment (Figure $7 \mathrm{~B}$ and C). These data demonstrate that the increase of HIF1 $\alpha$ induced by poly(I:C) occurs downstream of NF-kB and ERK activation. Since we showed that HIF1 $\alpha$ down-regulation by specific siRNA inhibited poly(I:C)-induced TLR3 up-regulation (Figure 5B), 
A
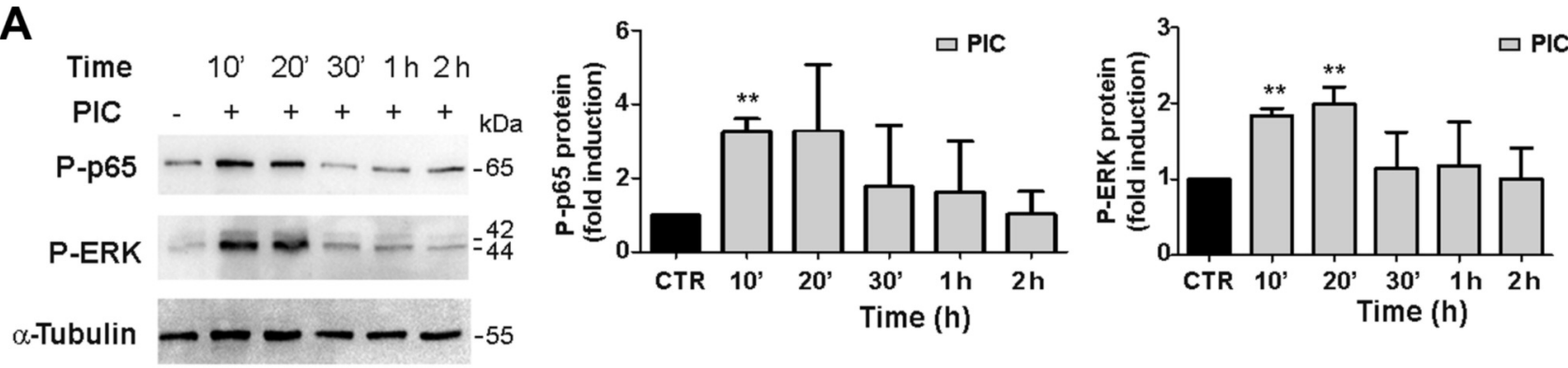

B

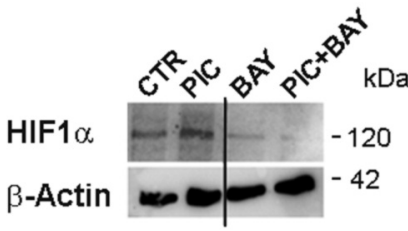

TLR3

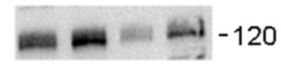

$\beta$-Actin
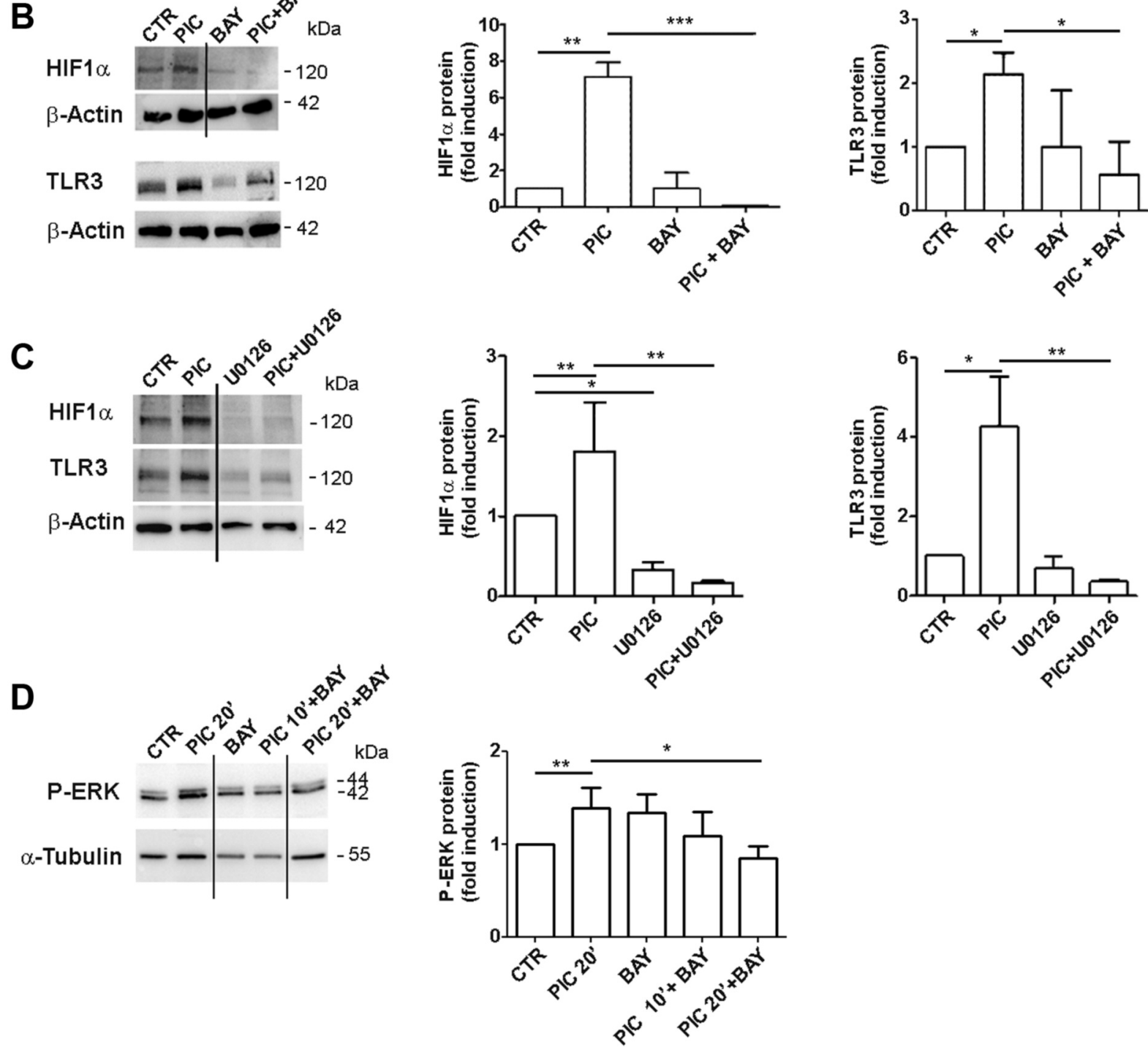

Figure 7. Toll-like receptor-3 (TLR3) and hypoxia-inducible factor $1 \alpha$ (HIF1 $\alpha)$ up-regulation induced by polyinosinic:polycytidylic acid (PIC) in $M D A-M B-231$ cells is downstream of nuclear factor ${ }_{k} B(N F-k B)$ and extracellular-regulated kinase (ERK) activation. A: MDA-MB-231 cells were treated with $25 \mu \mathrm{g} / \mathrm{ml}$ PIC for different times and whole-cell extracts were analyzed by western blot for phospho-( $p)-p 65$ and $p$-ERK proteins. B, C: Cells were treated with $10 \mu \mathrm{M} \mathrm{NF-kB}$ inhibitor BAY 11-7082 (B) or $10 \mu \mathrm{M}$ ERK inhibitor U0126 (C) in addition to $25 \mu \mathrm{g} / \mathrm{ml}$ PIC for $24 \mathrm{~h}$ and whole-cell extracts were analyzed by western blot for HIF1 $\alpha$ and TLR3 proteins. D: Cells were treated with $10 \mu M$ BAY 11-7082 in addition to 25 $\mu \mathrm{g} / \mathrm{ml}$ PIC for $24 \mathrm{~h}$ and whole-cell extracts analyzed by western blot for phospho-ERK. $\beta$-Actin and $\alpha$-tubulin were used as protein loading controls. The histograms represent the densitometric analysis of three separate experiments with the value for untreated cells set being as 1 . Significantly different from the control (CTR) at $* p<0.05, * * p<0.01$ and $* * * p<0.001$. 
we analyzed the effect of BAY 11-7082 and U0126 on TLR3 expression. As expected, NF-kB and ERK inhibition significantly reduced TLR3 expression (Figure 7B and C).

To investigate whether phospho-ERK is downstream of NF-kB in this signaling pathway, MDA-MB-231 cells were pre-treated for $1 \mathrm{~h}$ with BAY 11-7082, before adding poly(I:C). We detected reduced levels of phospho-ERK after treatment with BAY+poly(I:C), compared with poly(I:C) alone (Figure 7D). Conversely, treatment with phospho-ERK inhibitor U0126 failed to reduce phospho-p65 induction (data not shown). This demonstrates that the increase of phosphoERK after poly(I:C) occurs downstream of NF-KB activation.

Our findings are shown in a schematic model of downstream targets after poly(I:C)-induced HIF1 $\alpha$ upregulation by $\mathrm{NF}-\mathrm{kB}$ signaling pathway in human breast cancer cells (Figure 8).

\section{Discussion}

Stimulation of TLRs with microbial components may represent a double-edged sword in cancer: a signal that promotes a proinflammatory environment to enhance tumor growth and chemoresistance or a signal that directly induces tumor cell death and activation of antitumor immune response. Data previously obtained in our laboratory on human prostate cancer cell lines showed that poly(I:C) induces a strong TLR3mediated apoptotic response in $\mathrm{LNCaP}$ cells, whereas PC3 cells are less sensitive to this stimulus because of the upregulation of HIF1 $\alpha$ protein in this cancer cell line (25). More recently, an article reported that in the human breast cancer cell lines MDA-MB-231 and MCF-7, poly(I:C) treatment failed to induce apoptosis (51), but the mechanism of poly(I:C) resistance of these breast cancer cells has not been clarified yet. In the present work we show that apoptosis resistance of breast cancer cells is paralleled by increased expression and activity of HIF1 $\alpha$ protein. Considering the multifaceted roles of HIF1 $\alpha$ in tumor progression and metastasis, this specific pathway is a crucial target for many drugs and a combined therapeutic approach based on HIF1 $\alpha$ inhibitors and TLR3 agonist could represent a promising strategy.

Our results suggest that the overexpression of HIF $1 \alpha$ protein in human breast cancer cells might play a key role in resistance to poly(I:C) stimulation through both upregulation of pro-tumoral and anti-apoptotic proteins and, importantly, the induction of VM.

In the present study we observed that poly(I:C) treatment efficiently increased expression of the HIF1 $\alpha$ target c-MYC in MDA-MB-231 and MCF-7 cell lines and, interestingly, poly(I:C)-induced nuclear accumulation of c-MYC in MDAMB-231 cells suggests an increase of $\mathrm{c}-M Y C$ transcriptional activity, enhancing pro-tumor effects, which is in accordance with poly(I:C)-induced features in pharyngeal cancer cells (52). Accordingly, we detected a significant reduction of

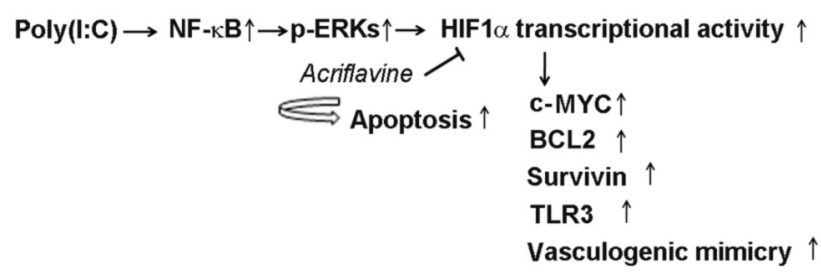

Figure 8. The scheme summarizes the effect of toll-like receptor-3 (TLR3) stimulation by its ligand polyinosinic:polycytidylic acid [poly $(I: C)]$ on the human triple-negative breast cancer cell line MDA-MB-231. PIC treatment activates the signal transduction pathway involving nuclear factor $k B(N F$ $\left.{ }_{k} B\right)$ and extracellular signal-regulated kinases (ERKs) resulting in increased levels and nuclear translocation of hypoxia-inducible factor $1 \alpha$ (HIF $1 \alpha)$, with consequent induction of HIF 1 transcriptional activity. HIF 1 activation mediates the increase of PIC receptor TLR3, and of the protumour and anti-apoptotic proteins $c-M Y C, B C L 2$ apoptosis regulator (BCL2) and survivin, and promotes a phenomenon involved in tumor progression called vasculogenic mimicry. Moreover, the inhibition of HIF 1 by acriflavine induces increased apoptosis of PIC-treated cells.

poly(I:C)-induced c-MYC protein after HIF1 $\alpha$ downregulation by siRNA. Unlike c-MYC, we observed an induction of different anti-apoptotic proteins after poly(I:C) treatment in two breast cancer cell lines according to HIF1 $\alpha$ expression increase, such as BCL2 up-regulation in MDAMB-231 cells and survivin increase in MCF-7 cells. This is in accordance with a report that HIF1 $\alpha$ is an important transcriptional regulator of survivin expression in non-small lung cell cancer (45) and in multiple myeloma (53).

Moreover, HIF1 $\alpha$-specific siRNA surprisingly led to a reduced level of TLR3. In our hypothesis, the TLR3 activator poly(I:C) induces HIF1 $\alpha$ accumulation, indicating that TLR3 is upstream of HIF1 $\alpha$ protein. However, it has been demonstrated in oral squamous cell carcinoma that activation of TLR3 stimulated the expression of HIF1 through NF-kB. In addition, HIF $1 \alpha$ increased the expression of TLR3 through direct promoter binding, thus, the TLR3-NF-kB pathway forms a positive feedback loop with HIF1 in oral squamous cell carcinoma (54). Our data highlight the existence of this regulatory loop also in our system.

VM plays an important role in cancer progression by providing an extra blood supply for a malignant tumor. Many studies reported that VM is related to hypoxia-activated signaling pathways and metastatic phenotype $(50,55)$. It has been demonstrated that the overexpression of HIF1 $\alpha$ protein is associated with VM in human gallbladder cell lines (56) as well as in breast cancer (57). TNBC is a subtype which is aggressive, metastasizes and has a poor prognosis. A previous study showed greater VM formation in patients with TNBC than in those with non-TNBC, which supports the hypothesis that VM formation is positively associated with life- threatening TNBC (58). Our present findings indicate that pharmacological and genetic HIF1 $\alpha$ inhibition significantly reduced channel formation, 
showing that HIF1 $\alpha$ is the crucial mediator of VM in human TNBC cell line MDA-MB-231. Moreover, to further verify HIF1 $\alpha$ involvement in VM, we mimicked hypoxia using cobalt chloride and observed a strong increase in vessel-like structure formation which was totally blocked by HIF1 $\alpha$ siRNA as well as in the presence of the pharmacological HIF1 inhibitor acriflavine. Altogether our data on TNBC agree with other studies in different tumor types $(57,59)$ and interestingly provide the first evidence that TLR3 stimulation induces HIF1 $\alpha$ mediated VM in a very aggressive breast cancer cell line.

Regarding signaling pathways upstream of poly(I:C)-induced HIF1 $\alpha$ in MDA-MB-231 cells, it is known that in normoxic conditions, several stimuli, such as cytokines and growth factors, up-regulate HIF1 $\alpha$ at the transcriptional level. Accordingly, we reported that stimulation of TLR3 with poly(I:C) increased HIF1 $\alpha$ mRNA expression in prostate cancer cells (25). Han et al.'s work demonstrated that up-regulation of HIF $1 \alpha$ is directly correlated with activation of TLR3 through NF-kB signaling (54). Similarly, in our work we investigated transcriptional factors and signaling upstream of poly(I:C)induced HIF1 $\alpha$ up-regulation and our data show that the increase of HIF1 $\alpha$ is dependent on NF-kB signaling, indicating that NF-kB may regulate $\mathrm{HIF} 1 \alpha$ gene transcription through binding with its promoter, as previously reported (60). Moreover, ERK-associated up-regulation of HIF1 $\alpha$ in pancreatic adenocarcinoma was shown (61). In accordance with these previous works, using specific inhibitors, we showed NF$\mathrm{KB}$-dependent ERK phosphorylation that is crucial in increasing HIF1 $\alpha$ and HIF1 $\alpha$-dependent TLR3 up-regulation.

Altogether our results indicate that up-regulation of HIF1 $\alpha$ protein in human breast cancer cells might play a key role in resistance to poly(I:C) stimulation through both induction of pro-tumoral and anti-apoptotic proteins and the increase of VM. Studies in vivo with combined treatment with poly(I:C) and HIF1 inhibitors are necessary to provide conclusive evidence for TLR3-mediated effects in breast cancer, contributing to the refinement of diagnostic tools and possibly the development of novel targeted therapeutic strategies.

\section{Conflicts of Interest}

The Authors declare that they have no conflicts of interest.

\section{Authors' Contributions}

Conceptualization, E.Z., A.R. and A.F.; methodology, F.S.; A.DA.; R.F.; software, R.F. and A.D.A; formal analysis, F.P.; investigation, F.S.; writing-original draft preparation, A.R. and P.DC; writingreview and editing, F.M. and A.F.; supervision, A.F.; A.R. and P.D.C; funding acquisition, A.F. and A.R.

\section{Acknowledgements}

The Authors thank Fioretta Palombi for critical reading and revision of the article.
This work was supported by Fondazione Roma (NCDs-201300000345) to A. F. and funding by Ateneo Sapienza University (Ref. Number RP11816427B97420 and RG11916B7AF0C02D).

\section{References}

1 Torre LA, Bray F, Siegel RL, Ferlay J, Lortet-Tieulent J and Jemal A: Global cancer statistics, 2012. CA Cancer J Clin 65(2): 87-108, 2015. PMID: 25651787. DOI: 10.3322/caac.21262

2 Brizel DM, Scully SP, Harrelson JM, Layfield LJ, Bean JM, Prosnitz LR and Dewhirst MW: Tumor oxygenation predicts for the likelihood of distant metastases in human soft tissue sarcoma. Cancer Res 56(5): 941-943, 1996. PMID: 8968082.

3 Zhong H, De Marzo AM, Laughner E, Lim M, Hilton DA, Zagzag D, Buechler P, Isaacs WB, Semenza GL and Simons JW: Overexpression of hypoxia-inducible factor 1alpha in common human cancers and their metastases. Cancer Res 59(22): 58305835, 1999. PMID: 10582706.

4 Lundgren K, Holm C and Landberg G: Hypoxia and breast cancer: Prognostic and therapeutic implications. Cell Mol Life Sci 64(24): 3233-3247, 2007. PMID: 17957335. DOI: 10.1007/ s00018-007-7390-6

5 Ke Q and Costa M: Hypoxia-inducible factor-1 (HIF1). Mol Pharmacol 70(5): 1469-1480, 2006. PMID: 16887934. DOI: 10.1124/mol.106.027029

6 Semenza GL, Jiang BH, Leung SW, Passantino R, Concordet JP, Maire $\mathrm{P}$ and Giallongo A: Hypoxia response elements in the aldolase $\mathrm{A}$, enolase 1 , and lactate dehydrogenase a gene promoters contain essential binding sites for hypoxia-inducible factor 1. J Biol Chem 271(51): 32529-32537, 1996. PMID: 8955077. DOI: $10.1074 /$ jbc.271.51.32529

7 Mees G, Dierckx R, Vangestel C and Van de Wiele C: Molecular imaging of hypoxia with radiolabelled agents. Eur J Nucl Med Mol Imaging 36(10): 1674-1686, 2009. PMID: 19565239. DOI: 10.1007/s00259-009-1195-9

8 Harris AL: Hypoxia-a key regulatory factor in tumour growth. Nat Rev Cancer 2(1): 38-47, 2002. PMID: 11902584. DOI: 10.1038/nrc704

9 Brune B and Zhou J: The role of nitric oxide (NO) in stability regulation of hypoxia inducible factor-1alpha (HIF1alpha). Curr Med Chem 10(10): 845-855, 2003. PMID: 12678687. DOI: 10.2174/0929867033457746

10 Gerber SA and Pober JS: IFN-alpha induces transcription of hypoxia-inducible factor-1alpha to inhibit proliferation of human endothelial cells. J Immunol 181(2): 1052-1062, 2008. PMID: 18606657. DOI: 10.4049/jimmunol.181.2.1052

11 Gorlach A and Kietzmann T: Superoxide and derived reactive oxygen species in the regulation of hypoxia-inducible factors. Methods Enzymol 435: 421-446, 2007. PMID: 17998067. DOI: 10.1016/S0076-6879(07)35022-2

12 Jung Y, Isaacs JS, Lee S, Trepel J, Liu ZG and Neckers L: Hypoxia-inducible factor induction by tumour necrosis factor in normoxic cells requires receptor-interacting protein-dependent nuclear factor kappa B activation. Biochem J 370(Pt 3): 10111017, 2003. PMID: 12479793. DOI: 10.1042/BJ20021279

13 Blouin CC, Page EL, Soucy GM and Richard DE: Hypoxic gene activation by lipopolysaccharide in macrophages: Implication of hypoxia-inducible factor 1alpha. Blood 103(3): 1124-1130, 2004. PMID: 14525767. DOI: 10.1182/blood-2003-07-2427

14 Nicholas SA and Sumbayev VV: The involvement of hypoxiainducible factor 1 alpha in toll-like receptor $7 / 8$-mediated 
inflammatory response. Cell Res 19(8): 973-983, 2009. PMID: 19381167. DOI: $10.1038 / \mathrm{cr} 2009.44$

15 Takeda K, Kaisho T and Akira S: Toll-like receptors. Annu Rev Immunol 21: 335-376, 2003. PMID: 12524386. DOI: 10.1146/ annurev.immunol.21.120601.141126

16 Huang B, Zhao J, Unkeless JC, Feng ZH and Xiong H: TLR signaling by tumor and immune cells: A double-edged sword. Oncogene 27(2): 218-224, 2008. PMID: 18176603. DOI: 10.1038/sj.onc.1210904

17 Yang H, Zhou H, Feng P, Zhou X, Wen H, Xie X, Shen H and Zhu X: Reduced expression of toll-like receptor 4 inhibits human breast cancer cells proliferation and inflammatory cytokine secretion. J Exp Clin Cancer Res 29: 92, 2010. PMID: 20618976. DOI: 10.1186/1756-9966-29-92

18 Salaun B, Coste I, Rissoan MC, Lebecque SJ and Renno T: TLR3 can directly trigger apoptosis in human cancer cells. J Immunol 176(8): 4894-4901, 2006. PMID: 16585585. DOI: 10.4049/jimmunol.176.8.4894

19 Salaun B, Zitvogel L, Asselin-Paturel C, Morel Y, Chemin K, Dubois C, Massacrier C, Conforti R, Chenard MP, Sabourin JC, Goubar A, Lebecque S, Pierres M, Rimoldi D, Romero P and Andre F: TLR3 as a biomarker for the therapeutic efficacy of double-stranded RNA in breast cancer. Cancer Res 71(5): 16071614, 2011. PMID: 21343393. DOI: 10.1158/0008-5472.CAN$10-3490$

20 Gonzalez-Reyes S, Marin L, Gonzalez L, Gonzalez LO, del Casar JM, Lamelas ML, Gonzalez-Quintana JM and Vizoso FJ: Study of TLR3, TLR4 and TLR9 in breast carcinomas and their association with metastasis. BMC Cancer 10: 665, 2010. PMID: 21129170. DOI: $10.1186 / 1471-2407-10-665$

21 Jia D, Yang W, Li L, Liu H, Tan Y, Ooi S, Chi L, Filion LG, Figeys D and Wang L: Beta-catenin and NF-kappaB coactivation triggered by TLR3 stimulation facilitates stem celllike phenotypes in breast cancer. Cell Death Differ 22(2): 298310, 2015. PMID: 25257174. DOI: 10.1038/cdd.2014.145

22 Schwartz AL, Dickerson E, Dagia N, Malgor R and McCall KD: TLR signaling inhibitor, phenylmethimazole, in combination with tamoxifen inhibits human breast cancer cell viability and migration. Oncotarget 8(69): 113295-113302, 2017. PMID: 29371911. DOI: $10.18632 /$ oncotarget. 10358

23 Paone A, Starace D, Galli R, Padula F, De Cesaris P, Filippini A, Ziparo E and Riccioli A: Toll-like receptor 3 triggers apoptosis of human prostate cancer cells through a PKC-alphadependent mechanism. Carcinogenesis 29(7): 1334-1342, 2008. PMID: 18566014. DOI: 10.1093/carcin/bgn149

24 Gambara G, Desideri M, Stoppacciaro A, Padula F, De Cesaris P, Starace D, Tubaro A, Del Bufalo D, Filippini A, Ziparo E and Riccioli A: TLR3 engagement induces IRF-3-dependent apoptosis in androgen-sensitive prostate cancer cells and inhibits tumour growth in vivo. J Cell Mol Med 19(2): 327-339, 2015. PMID: 25444175. DOI: 10.1111/jcmm.12379

25 Paone A, Galli R, Gabellini C, Lukashev D, Starace D, Gorlach A, De Cesaris P, Ziparo E, Del Bufalo D, Sitkovsky MV, Filippini A and Riccioli A: Toll-like receptor 3 regulates angiogenesis and apoptosis in prostate cancer cell lines through hypoxia-inducible factor 1 alpha. Neoplasia 12(7): 539-549, 2010. PMID: 20651983. DOI: 10.1593/neo.92106

26 Saito S, Lin YC, Tsai MH, Lin CS, Murayama Y, Sato R and Yokoyama KK: Emerging roles of hypoxia-inducible factors and reactive oxygen species in cancer and pluripotent stem cells.
Kaohsiung J Med Sci 31(6): 279-286, 2015. PMID: 26043406. DOI: $10.1016 /$ j.kjms.2015.03.002

27 Paulis YW, Soetekouw PM, Verheul HM, Tjan-Heijnen VC and Griffioen AW: Signalling pathways in vasculogenic mimicry. Biochim Biophys Acta 1806(1): 18-28, 2010. PMID: 20079807. DOI: $10.1016 /$ j.bbcan.2010.01.001

28 Hendrix MJ, Seftor EA, Hess AR and Seftor RE: Vasculogenic mimicry and tumour-cell plasticity: Lessons from melanoma. Nat Rev Cancer 3(6): 411-421, 2003. PMID: 12778131. DOI: $10.1038 /$ nrc 1092

29 Maniotis AJ, Folberg R, Hess A, Seftor EA, Gardner LM, Pe'er J, Trent JM, Meltzer PS and Hendrix MJ: Vascular channel formation by human melanoma cells in vivo and in vitro: Vasculogenic mimicry. Am J Pathol 155(3): 739-752, 1999. PMID: 10487832. DOI: 10.1016/S0002-9440(10)65173-5

30 Vartanian AA, Stepanova EV, Gutorov SL, Solomko E, Grigorieva IN, Sokolova IN, Baryshnikov AY and Lichinitser MR: Prognostic significance of periodic acid-schiff-positive patterns in clear cell renal cell carcinoma. Can J Urol 16(4): 4726-4732, 2009. PMID: 19671223.

31 Baeten CI, Hillen F, Pauwels P, de Bruine AP and Baeten CG: Prognostic role of vasculogenic mimicry in colorectal cancer. Dis Colon Rectum 52(12): 2028-2035, 2009. PMID: 19934926. DOI: $10.1007 / D C R .0 b 013 e 3181$ beb4ff

32 Wang H, Lin H, Pan J, Mo C, Zhang F, Huang B, Wang Z, Chen $\mathrm{X}$, Zhuang J, Wang D and Qiu S: Vasculogenic mimicry in prostate cancer: The roles of EPHA2 and PI3K. J Cancer 7(9): 1114-1124, 2016. PMID: 27326255. DOI: 10.7150/jca.14120

33 El Hallani S, Boisselier B, Peglion F, Rousseau A, Colin C, Idbaih A, Marie Y, Mokhtari K, Thomas JL, Eichmann A, Delattre JY, Maniotis AJ and Sanson M: A new alternative mechanism in glioblastoma vascularization: Tubular vasculogenic mimicry. Brain 133(Pt 4): 973-982, 2010. PMID: 20375132. DOI: 10.1093/brain/awq044

34 Sood AK, Fletcher MS, Zahn CM, Gruman LM, Coffin JE, Seftor EA and Hendrix MJ: The clinical significance of tumor cell-lined vasculature in ovarian carcinoma: Implications for anti-vasculogenic therapy. Cancer Biol Ther 1(6): 661-664, 2002. PMID: 12642690. DOI: $10.4161 / \mathrm{cbt} .316$

35 Li M, Gu Y, Zhang Z, Zhang S, Zhang D, Saleem AF, Zhao X and Sun B: Vasculogenic mimicry: A new prognostic sign of gastric adenocarcinoma. Pathol Oncol Res 16(2): 259-266, 2010. PMID: 20016961. DOI: 10.1007/s12253-009-9220-7

36 Sun B, Zhang S, Zhang D, Du J, Guo H, Zhao X, Zhang W and Hao X: Vasculogenic mimicry is associated with high tumor grade, invasion and metastasis, and short survival in patients with hepatocellular carcinoma. Oncol Rep 16(4): 693-698, 2006. PMID: 16969481, DOI: 10.3892/or.16.4.693

37 Wang W, Lin P, Han C, Cai W, Zhao X and Sun B: Vasculogenic mimicry contributes to lymph node metastasis of laryngeal squamous cell carcinoma. J Exp Clin Cancer Res 29: 60, 2010. PMID: 20525189. DOI: 10.1186/1756-9966-29-60

38 Shirakawa K, Wakasugi H, Heike Y, Watanabe I, Yamada S, Saito K and Konishi F: Vasculogenic mimicry and pseudocomedo formation in breast cancer. Int J Cancer 99(6): 821-828, 2002. PMID: 12115483. DOI: 10.1002/ijc. 10423

39 Wang F, Chang M, Shi Y, Jiang L, Zhao J, Hai L, Sharen G and Du $\mathrm{H}$ : Down-regulation of hypoxia-inducible factor-1 suppresses malignant biological behavior of triple-negative breast cancer cells. Int J Clin Exp Med 7(11): 3933-3940, 2014. PMID: 25550901. 
40 Falchook GS, Wheler JJ, Naing A, Jackson EF, Janku F, Hong D, Ng CS, Tannir NM, Lawhorn KN, Huang M, Angelo LS, Vishwamitra D, Hess K, Howard AN, Parkhurst KL, Amin HM and Kurzrock R: Targeting hypoxia-inducible factor-1alpha (HIF1alpha) in combination with antiangiogenic therapy: A phase I trial of bortezomib plus bevacizumab. Oncotarget 5(21): 10280-10292, 2014. PMID: 25373733. DOI: $10.18632 /$ oncotarget.2163

41 Semenza GL: Regulation of the breast cancer stem cell phenotype by hypoxia-inducible factors. Clin Sci 129(12): 10371045, 2015. PMID: 26405042. DOI: 10.1042/CS20150451

42 Palchetti S, Starace D, De Cesaris P, Filippini A, Ziparo E and Riccioli A: Transfected poly(I:C) activates different dsrna receptors, leading to apoptosis or immunoadjuvant response in androgenindependent prostate cancer cells. J Biol Chem 290(9): 5470-5483, 2015. PMID: 25568326. DOI: 10.1074/jbc.M114.601625

43 Xu Z, Liu E, Peng C, Li Y, He Z, Zhao C and Niu J: Role of hypoxia-inducible-1alpha in hepatocellular carcinoma cells using a TET-on inducible system to regulate its expression in vitro. Oncol Rep 27(2): 573-578, 2012. PMID: 22075557. DOI: 10.3892/or.2011.1533

44 Mathieu J, Zhang Z, Zhou W, Wang AJ, Heddleston JM, Pinna CM, Hubaud A, Stadler B, Choi M, Bar M, Tewari M, Liu A, Vessella R, Rostomily R, Born D, Horwitz M, Ware C, Blau CA, Cleary MA, Rich JN and Ruohola-Baker H: HIF induces human embryonic stem cell markers in cancer cells. Cancer Res 71(13): 4640-4652, 2011. PMID: 21712410. DOI: 10.1158/0008-5472.CAN-10-3320

45 Chen YQ, Zhao CL and Li W: Effect of hypoxia-inducible factor-1alpha on transcription of survivin in non-small cell lung cancer. J Exp Clin Cancer Res 28: 29, 2009. PMID: 19245702. DOI: $10.1186 / 1756-9966-28-29$

46 Chen N, Chen X, Huang R, Zeng H, Gong J, Meng W, Lu Y, Zhao F, Wang L and Zhou Q: BCL-xl is a target gene regulated by hypoxia-inducible factor-1 \{alpha\}. J Biol Chem 284(15): 10004-10012, 2009. PMID: 19211554. DOI: 10.1074/jbc. M805997200

47 Peng XH, Karna P, Cao Z, Jiang BH, Zhou M and Yang L: Cross-talk between epidermal growth factor receptor and hypoxia-inducible factor-1alpha signal pathways increases resistance to apoptosis by up-regulating survivin gene expression. J Biol Chem 281(36): 25903-25914, 2006. PMID: 16847054. DOI: $10.1074 /$ jbc.M603414200

48 Inao T, Harashima N, Monma H, Okano S, Itakura M, Tanaka T, Tajima Y and Harada M: Antitumor effects of cytoplasmic delivery of an innate adjuvant receptor ligand, poly(I:C), on human breast cancer. Breast Cancer Res Treat 134(1): 89-100, 2012. PMID: 22203435. DOI: 10.1007/s10549-011-1930-3

49 Lee K, Zhang H, Qian DZ, Rey S, Liu JO and Semenza GL: Acriflavine inhibits HIF1 dimerization, tumor growth, and vascularization. Proc Natl Acad Sci USA 106(42): 17910-17915, 2009. PMID: 19805192. DOI: 10.1073/pnas.0909353106

50 Guo X, Xu S, Gao X, Wang J, Xue H, Chen Z, Zhang J, Guo X, Qian M, Qiu W and Li G: Macrophage migration inhibitory factor promotes vasculogenic mimicry formation induced by hypoxia via CXCR4/AKT/EMT pathway in human glioblastoma cells. Oncotarget 8(46): 80358-80372, 2017. PMID: 29113309. DOI: 10.18632/oncotarget.18673

51 Bondhopadhyay B, Moirangthem A and Basu A: Innate adjuvant receptor toll-like receptor 3 can promote breast cancer through cell surface. Tumour Biol 36(2): 1261-1271, 2015. PMID: 25348355. DOI: $10.1007 / \mathrm{s} 13277-014-2737-8$
52 Glavan TM, Gasparovic AC, Verillaud B, Busson P and Pavelic $\mathrm{J}$ : Toll-like receptor 3 stimulation triggers metabolic reprogramming in pharyngeal cancer cell line through MYC, MAPK, and HIF. Molecular Carcinogenesis 56(4): 1214-1226, 2017. PMID: 27805282 . DOI: $10.1002 / \mathrm{mc} .22584$

53 Tsubaki M, Takeda T, Tomonari Y, Koumoto YI, Imano M, Satou T and Nishida S: Overexpression of HIF1alpha contributes to melphalan resistance in multiple myeloma cells by activation of ERK1/2, AKT, and NF-KappaB. Lab Invest 99(1): 72-84, 2019. PMID: 30353128. DOI: 10.1038/s41374-018-0114-8

54 Han S, Xu W, Wang Z, Qi X, Wang Y, Ni Y, Shen H, Hu Q and Han W: Crosstalk between the HIF1 and toll-like receptor/nuclear factor-kappaB pathways in the oral squamous cell carcinoma microenvironment. Oncotarget 7(25): 37773 37789, 2016. PMID: 27191981. DOI: 10.18632/oncotarget.9329

55 Zhao N, Sun BC, Sun T, Ma YM, Zhao XL, Liu ZY, Dong XY, Che N, Mo J and Gu Q: Hypoxia-induced vasculogenic mimicry formation via $\mathrm{VE}-\mathrm{cadherin}$ regulation by BCL-2. Med Oncol 29(5): 3599-3607, 2012. PMID: 22562824. DOI: 10.1007/ s12032-012-0245-5

56 Sun W, Shen ZY, Zhang H, Fan YZ, Zhang WZ, Zhang JT, Lu $\mathrm{XS}$ and $\mathrm{Ye} \mathrm{C}$ : Overexpression of HIF1alpha in primary gallbladder carcinoma and its relation to vasculogenic mimicry and unfavourable prognosis. Oncol Rep 27(6): 1990-2002, 2012. PMID: 22470047. DOI: 10.3892/or.2012.1746

57 Wang Y, Sun H, Zhang D, Fan D, Zhang Y, Dong X, Liu S, Yang Z, Ni C, Li Y, Liu F and Zhao X: TP53INP1 inhibits hypoxiainduced vasculogenic mimicry formation via the ROS/SNAIL signalling axis in breast cancer. J Cell Mol Med 22(7): 34753488, 2018. PMID: 29655255. DOI: $10.1111 / \mathrm{jcmm} .13625$

58 Liu TJ, Sun BC, Zhao XL, Zhao XM, Sun T, Gu Q, Yao Z, Dong $\mathrm{XY}$, Zhao $\mathrm{N}$ and Liu N: CD133+ cells with cancer stem cell characteristics associates with vasculogenic mimicry in triplenegative breast cancer. Oncogene 32(5): 544-553, 2013. PMID: 22469978. DOI: $10.1038 /$ onc.2012.85

59 van der Schaft DW, Hillen F, Pauwels P, Kirschmann DA, Castermans K, Egbrink MG, Tran MG, Sciot R, Hauben E, Hogendoorn PC, Delattre O, Maxwell PH, Hendrix MJ and Griffioen AW: Tumor cell plasticity in Ewing sarcoma, an alternative circulatory system stimulated by hypoxia. Cancer Res 65(24): 11520-11528, 2005. PMID: 16357161. DOI: 10.1158/ 0008-5472.CAN-05-2468

60 Rius J, Guma M, Schachtrup C, Akassoglou K, Zinkernagel AS, Nizet V, Johnson RS, Haddad GG and Karin M: NF-kappaB links innate immunity to the hypoxic response through transcriptional regulation of HIF1alpha. Nature 453(7196): 807811, 2008. PMID: 18432192. DOI: 10.1038/nature06905

$61 \mathrm{Wu}$ Y, Meitzler JL, Antony S, Juhasz A, Lu J, Jiang G, Liu H, Hollingshead M, Haines DC, Butcher D, Panter MS, Roy K and Doroshow JH: Dual oxidase 2 and pancreatic adenocarcinoma: IFN-gamma-mediated dual oxidase 2 overexpression results in $\mathrm{H}_{2} \mathrm{O}_{2}$-induced, ERK-associated up-regulation of HIF1alpha and VEGF-A. Oncotarget 7(42): 68412-68433, 2016. PMID: 27637085. DOI: $10.18632 /$ oncotarget.12032

Received June 18, 2020

Revised July 12, 2020

Accepted July 14, 2020 